\title{
Mineral Resources of the
}

Home Creek Wilderness Study Area

Harney County, Oregon

\section{U.S. GEOLOGICAL SURVEY BULLETIN 1740-C}

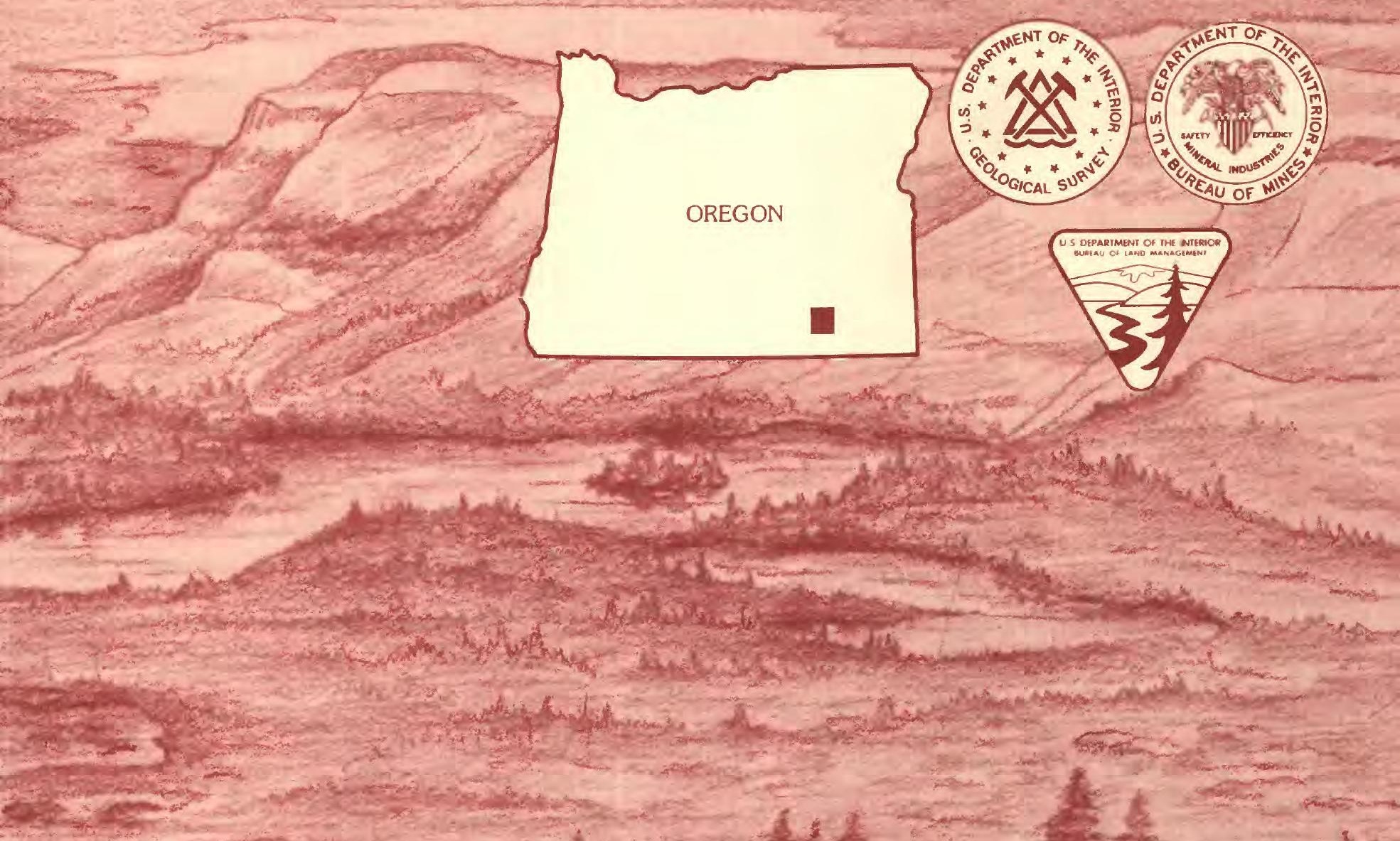




\section{AVAILABILITY OF BOOKS AND MAPS OF THE U.S. GEOLOGICAL SURVEY}

Instructions on ordering publications of the U.S. Geological Survey, along with prices of the last offerings, are given in the current-year issues of the monthly catalog "New Publications of the U.S. Geological Survey." Prices of available U.S. Geological Survey publications released prior to the current year are listed in the most recent annual "Price and Availability List." Publications that are listed in various U.S. Geological Survey catalogs (see back inside cover) but not listed in the most recent annual "Price and Availability List" are no longer available.

Prices of reports released to the open files are given in the listing "U.S. Geological Survey Open-File Reports," updated month$1 \mathrm{y}$, which is for sale in microfiche from the U.S. Geological Survey, Books and Open-File Reports Section, Federal Center, Box 25425 , Denver, CO 80225 . Reports released through the NTIS may be obtained by writing to the National Technical Information Service, U.S. Department of Commerce, Springfield, VA 22161; please include NTIS report number with inquiry.

Order U.S. Geological Survey publications by mail or over the counter from the offices given below.

\section{BY MAIL}

\section{Books}

Professional Papers, Bulletins, Water-Supply Papers, Techniques of Water-Resources Investigations, Circulars, publications of general interest (such as leaflets, pamphlets, booklets), single copies of Earthquakes \& Volcanoes, Preliminary Determination of Epicenters, and some miscellaneous reports, including some of the foregoing series that have gone out of print at the Superintendent of Documents, are obtainable by mail from

\section{U.S. Geological Survey, Books and Open-File Reports Federal Center, Box 25425 \\ Denver, CO 80225}

Subscriptions to periodicals (Earthquakes \& Volcanoes and Preliminary Determination of Epicenters) can be obtained ONLY from the

\section{Superintendent of Documents \\ Government Printing Omice \\ Washington, D.C. 20402}

(Check or money order must be payable to Superintendent of Documents.)

\section{Maps}

For maps, address mail orders to

$$
\begin{gathered}
\text { U.S. Geological Survey, Map Distribution } \\
\text { Federal Center, Box } 25286 \\
\text { Denver, CO } 80225
\end{gathered}
$$

Residents of Alaska may order maps from

$$
\begin{gathered}
\text { Alaska Distribution Section, U.S. Geological Survey, } \\
\text { New Federal Bullding - Box } 12 \\
101 \text { Twelfth A ve., Fairbanks, AK } 99701
\end{gathered}
$$

\section{OVER THE COUNTER}

\section{Books}

Books of the U.S. Geological Survey are available over the counter at the following Geological Survey Public Inquiries Offices, all of which are authorized agents of the Superintendent of Documents:

- WASHINGTON, D.C.--Main Interior Bldg., 2600 corridor, 18th and C Sts., NW.

- DENVER, Colorado--Federal Bldg., Rm. 169, 1961 Stout St.

- LOS ANGELES, California--Federal Bldg., Rm. 7638, $300 \mathrm{~N}$. Los Angeles St.

- MENLO PARK, Callfornia--Bldg. 3 (Stop 533), Rm. 3128, 345 Middlefield Rd.

- RESTON, Virginia--503 National Center, Rm. 1C402, 12201 Sunrise Valley Dr.

- SALT LAKE CITY, Utah--Federal Bldg., Rm. 8105, 125 South State St.

- SAN FRANCISCO, California--Customhouse, Rm. 504, 555 Battery St.

- SPOKANE, WashIngton--U.S. Courthouse, Rm. 678, West 920 Riverside Ave..

- ANCHORAGE, Alaska--Rm. 101, 4230 University Dr.

- ANCHORAGE, Alaska--Federal Bldg, Rm. E-146, 701 C St.

\section{Maps}

Maps may be purchased over the counter at the U.S. Geological Survey offices where books are sold (all addresses in above list) and at the following Geological Survey offices:

- ROLLA, Missourl--1400 Independence Rd.

- DENVER, Colorado--Map Distribution, Bldg. 810, Federal Center

- FAIRBANKS, Alaska--New Federal Bldg., 101 Twelfth Ave. 
Chapter C

Mineral Resources of the

Home Creek Wilderness Study Area, Harney County, Oregon

BY DEAN B. VANDER MEULEN, ANDREW GRISCOM, HARLEY D. KING, and THOMAS L. VERCOUTERE

U.S. Geological Survey

PHILLIP R. MOYLE

U.S. Bureau of Mines

U.S. GEOLOGICAL SURVEY BULLETIN 1740

MINERAL RESOURCES OF WILDERNESS STUDY AREAS:

STEENS MOUNTAIN-RINCON REGION, OREGON 


\title{
DEPARTMENT OF THE INTERIOR DONALD PAUL HODEL, Secretary
}

\author{
U.S. GEOLOGICAL SURVEY
}

Dallas L. Peck, Director

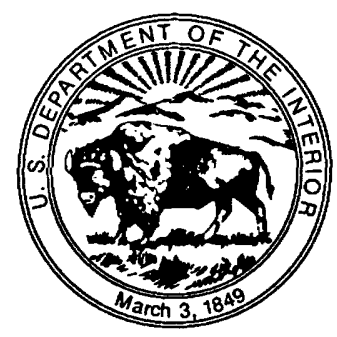

Any use of trade names and trademarks in this publication is for descriptive purposes only and does not constitute endorsement by the U.S. Geological Survey

For sale by the

Books and Open-File Reports Section

U.S. Geological Survey

Federal Center, Box 25425

Denver, CO 80225

Library of Congress Cataloging-in-Publication Data

Mineral resources of the Home Creek Wilderness Study Area, Harney County, Oregon.

(Mineral resources of wilderness study areas-Steens Mountain-Rincon region, Oregon ; ch. C) (U.S.

Geological Survey bulletin ; 1740)

Bibliography: $p$.

Supt. of Docs. no.: I 19.3:1740-C

1. Mines and mineral resources-Oregon-Home Creek Wilderness. 2. Home Creek Wilderness (Or.) I. Vander Meulen, Dean B. II. Series. III. Series: U.S. Geological Survey bulletin ; $1740-\mathrm{C}$.

QE75.B9 no. $1740-\mathrm{C} \quad 557.3 \mathrm{~s}$

[TN24.07] 


\section{STUDIES RELATED TO WILDERNESS}

\section{Bureau of Land Management Study Area}

The Federal Land Policy and Management Act (Public Law 94-579, October 21, 1976) requires the U.S. Geological Survey and the U.S. Bureau of Mines to conduct mineral surveys on certain areas to determine the mineral values, if any, that may be present. Results must be made available to the public and be submitted to the President and the Congress. This report presents the results of a mineral survey of part of the Home Creek Wilderness Study Area (OR-002-085H), Harney County, Oregon. 



\section{CONTENTS}

Summary C1

Abstract C1

Character and setting $\mathbf{C 1}$

Identified resources $\mathbf{C 1}$

Mineral resource potential C1

Introduction $\mathbf{C 3}$

Area description $\mathbf{C 3}$

Previous and present investigations C3

Appraisal of identified resources $\mathbf{C 3}$

History and production $\mathbf{C 3}$

Mines, prospects, claims, and mineralized areas C5

Appraisal of mineral resources C5

Assessment of mineral resource potential C5

Geology C5

Geochemical studies C6

Geophysical studies C7

Mineral resource assessment $\mathbf{C 7}$

References cited C8

Appendixes

Definition of levels of mineral resource potential and certainty of assessment $\quad$ C10

Resource/reserve classification $\mathbf{C 1 1}$

Geologic time chart $\mathbf{C 1 2}$

\section{FIGURES}

1. Index map showing location of Home Creek Wilderness Study Area, Harney County, Oregon

2. Map showing generalized geology and mineral resource potential of Home Creek Wilderness

Study Area, Harney County, Oregon C4 



\title{
Mineral Resources of the Home Creek Wilderness Study Area, Harney County, Oregon
}

\author{
By Dean B. Vander Meulen, Andrew Griscom, Harley D. King, and \\ Thomas L. Vercoutere \\ U.S. Geological Survey
}

Phillip R. Moyle

U.S. Bureau of Mines

\section{SUMMARY}

\begin{abstract}
Mineral surveys of 22,015 acres of the Home Creek Wilderness Study Area $(\mathrm{OR}-002-085 \mathrm{H})$ were conducted at the request of the Bureau of Land Management. In this report, the area studied is referred to as the "wilderness study area," or simply the "study area." The study area is adjacent to the Catlow Rim on the western slope of Steens Mountain in southeastern Oregon. Field work was conducted by the U.S. Geological Survey during 1986 and 1987 and by the U.S. Bureau of Mines during 1986 to evaluate the identified mineral resources (known) and the mineral resource potential (undiscovered) of the study area.

No mineral resources were identified in the study area. However, the study indicates low potential for silver resources in a small area near the central part of the study area, moderate potential for sand and gravel resources in lake shoreline deposits located within and adjacent to the western part of the study area, and low potential for geothermal energy throughout the study area. There is no resource potential for oil and gas in the study area.
\end{abstract}

\section{Character and Setting}

The Home Creek Wilderness Study Area (fig. 1) is located along the crest of the Catlow Rim, approximately $65 \mathrm{mi}$ south of Burns, Oreg. and $20 \mathrm{mi}$ northwest of Fields, Oreg. The Catlow Rim is a composite fault scarp that rises

Manuscript approved for publication June 21, 1988.
1,000 to $1,900 \mathrm{ft}$ above Catlow Valley and forms the entire length of the impressive 60 -mi-long east valley wall. The scarp is the dominant geologic structure in the region and forms part of the west margin of the $30-$ by $90-\mathrm{mi}$, northtrending Steens Mountain-Pueblo Mountains fault block. Most of the study area is located on the Steens Mountain dip slope, a gentle west-tilted plateau. Several west-flowing creeks cut the plateau (fig. 1).

The oldest rocks exposed in the study area are basalt flows of middle Miocene age ( 5 to 24 million years before present, or $\mathrm{Ma}$; see appendixes for geologic time chart). The basalt flows underlie the entire study area and form the 1,900-ft-high Catlow Rim escarpment (fig. 2). A Miocene rhyolite ash-flow tuff overlies the basalt flows in the northern and eastern parts of the study area. The west margin of the study area is located in Catlow Valley, a broad irregularly shaped basin. Pleistocene shoreline deposits and Holocene dunes are exposed in the valley.

\section{Identified Resources}

No mines, claims, prospects, or mineralized zones are present, and no mineral or energy resources or occurrences are identified within or adjacent to the study area.

\section{Mineral Resource Potential}

Part of a stream drainage and adjacent outcrops of ashflow tuff in the east-central part of the study area have low potential for silver resources (fig. 2). An anomalous 


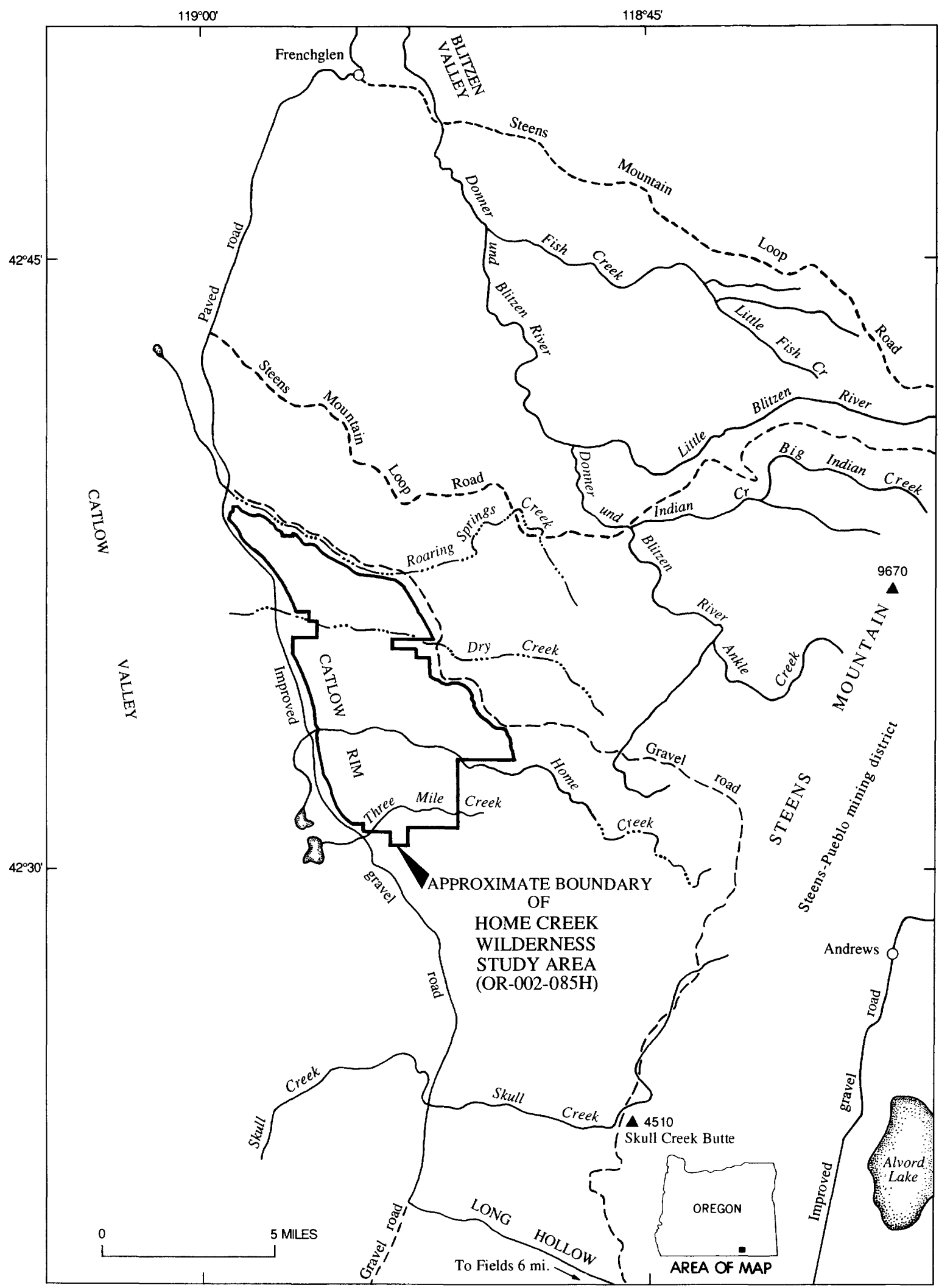

Figure 1. Index map showing location of Home Creek Wilderness Study Area, Harney County, Oregon. 
concentration of silver was recorded in a heavy-mineralconcentrate sample collected down-slope from the rhyolite ash-flow tuff. The tuff is part of the Devine Canyon Ashflow Tuff.

Shoreline gravel bar deposits located $12 \mathrm{mi}$ south of the study area have been utilized for aggregate. Bar deposits of the same shorelines form extensive terraces along the base of Catlow Rim within the western part of the study area (fig. 2). The bar deposits have moderate potential for sand and gravel resources.

Geothermal springs were not identified in or near the study area, although low-temperature geothermal springs that issue from fault zones 12 mi north of the study area do have potential for direct-heat application. Geologic structures such as recently active fault zones capable of producing geothermal energy may exist in the study area. The study area has low potential for geothermal energy. There is no oil and gas potential in the study area.

\section{INTRODUCTION}

This mineral survey was requested by the U.S. Bureau of Land Management and is a joint effort by the U.S. Geological Survey and U.S. Bureau of Mines. An introduction to the wilderness review process, mineral survey methods, and agency responsibilities was provided by Beikman and others (1983). The U.S. Bureau of Mines evaluates identified resources at individual mines and known mineralized areas by collecting data on current and past mining activities and through field examination of mines, prospects, claims, and mineralized areas. Identified resources are classified according to a system that is a modification of that described by McKelvey (1972) and U.S. Bureau of Mines and U.S. Geological Survey (1980). Studies by the U.S. Geological Survey are designed to provide a reasonable scientific basis for assessing the potential for undiscovered mineral resources by determining geologic units and structures, possible environments of mineral deposition, presence of geochemical and geophysical anomalies, and applicable ore-deposit models. Mineral assessment methodology and terminology as they apply to these surveys were discussed by Goudarzi (1984). See appendixes for the definition of levels of mineral resource potential and certainty of assessment, and for the resource/ reserve classification.

\section{Area Description}

The Home Creek Wilderness Study Area (OR002-085H) encompasses 22,015 acres in the northern Basin and Range physiographic province of southeastern Oregon. The study area is located along the east side of Catlow Valley approximately $14 \mathrm{mi}$ south of Frenchglen, Oreg. (fig. 1). The study area is accessible by an improved gravel road that parallels the west side of Catlow Rim and several unimproved dirt roads and jeep trails that approach the study area from the north and south. Maximum elevation in the study area is approximately $6,500 \mathrm{ft}$ above sea level at the southwest edge, and minimum elevation is about $4,600 \mathrm{ft}$ along the base of Catlow Rim. The climate is semiarid; Juniper groves are common along Catlow Rim and in protected canyons, and sage brush and grasses are dominant at lower elevations. The study area is currently used for cattle grazing.

\section{Previous and Present Investigations}

Previous geologic investigations that include the study area are a reconnaissance geologic map of the Adel $1^{\circ}$ by $2^{\circ}$ quadrangle by Walker and Repenning (1965), an aerial radiometric and magnetic survey by the U.S. Department of Energy (Geodata International, Inc., 1980), and an acromagnetic survey by the U.S. Geological Survey (1972). The U.S. Geological Survey conducted a combined geologic, geochemical, and geophysical survey of the wilderness study area during 1986 and 1987. Field investigations were focused on correlating geochemical and geophysical anomalies with rock units and geologic structures.

Investigations by the U.S. Bureau of Mines entailed prefield, field and report-preparation phases during 1986. Prefield studies included library research and perusal of Harney County and U.S. Bureau of Land Management mining and mineral lease records. Field studies involved searches for mineralized zones within the study area. Ground and aerial reconnaissance were conducted in an attempt to identify areas of alteration where mining activity might have taken place. Additional information is available from the U.S. Bureau of Mines, Western Field Operations Center, E. 360 Third Avenue, Spokane, WA 99202.

\section{APPRAISAL OF IDENTIFIED RESOURCES}

By Phillip R. Moyle

U.S. Bureau of Mines

\section{History and Production}

The Home Creek Wilderness Study Area is about 10 mi west of the Steens-Pucblo mining district, which lies along the east escarpment of the Steens Mountain-Pueblo Mountains fault block (Bradley, 1982). Small quantities of mercury were produced from the district (Ross, 1942; Williams and Compton, 1953). A small marginal perlite reserve and occurrences of gold, mercury, uranium, molybdenum, and zeolite mincrals were noted in or near the High Stcens Wilderness Study Area (Minor and others, 1987), about $10 \mathrm{mi}$ east of the Home Creek Wilderness Study 


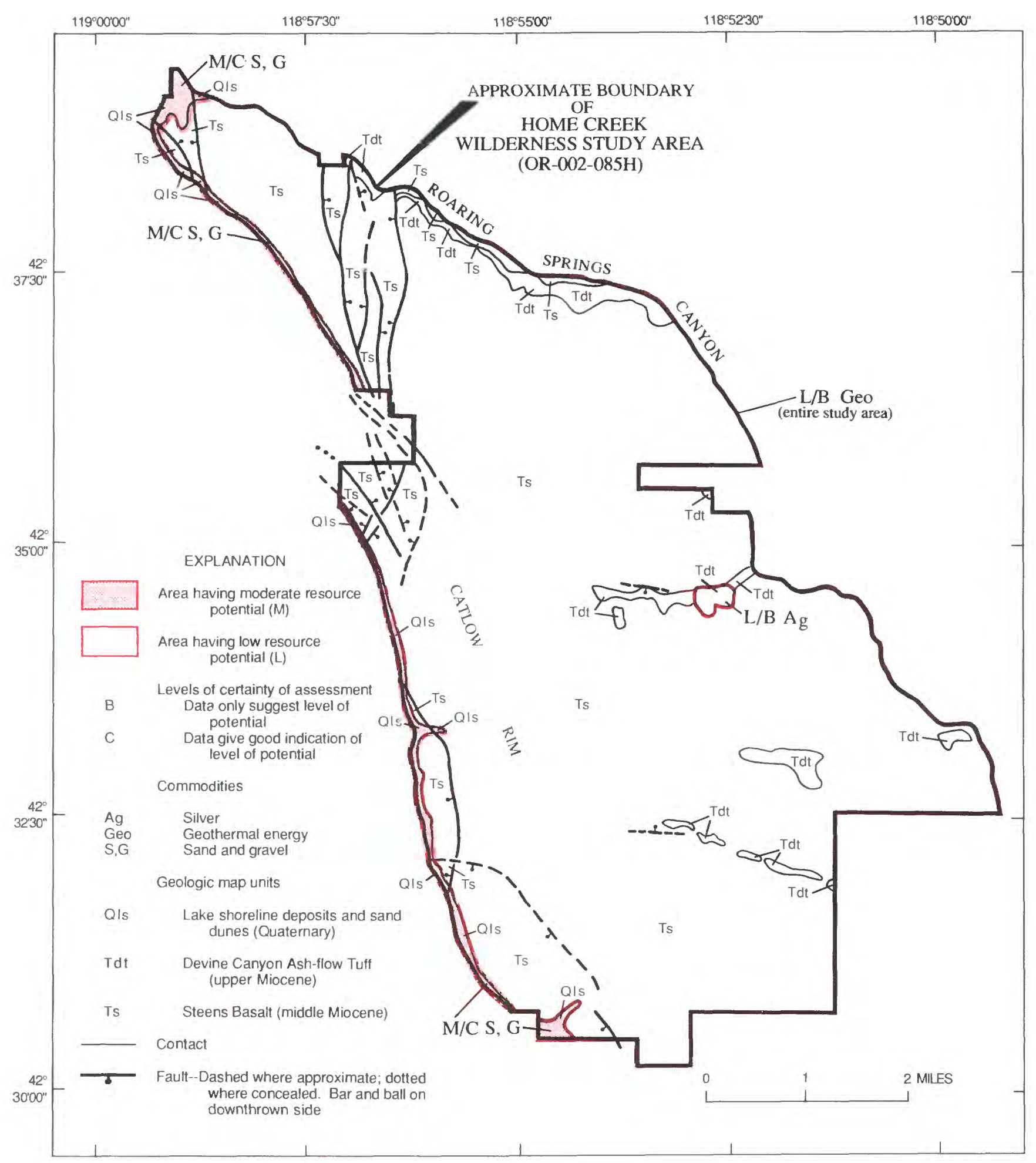

Figure 2. Generalized geologic map and mineral resource potential of Home Creek Wilderness Study Area, Harney County, Oregon. 
Area. Within the past 5 years, a company exploring for epithermal gold deposits has conducted reconnaissance sampling on the western flank of Steens Mountain (George Brown, written commun., 1986). However, no claims have been located, no mineral production has been recorded, and no workings were in evidence in or adjacent to the study area.

\section{Mines, Prospects, Claims, and Mineralized Areas}

No mine or prospect workings are present, and no mineralized areas were found within or near the study area. Furthermore, no gold was recovered from eight reconnaissance placer samples taken by the U.S. Bureau of Mines from drainages within and adjacent to the study area. Stream-sediment samples, partially concentrated in the field, were further concentrated on a laboratory-sized Wilfley table to separate heavy minerals, such as gold, from a lower density gangue. The concentrates were scanned with a binocular microscope to determine heavymineral content. Concentrates were also checked for radioactivity and fluorescence.

In the nearby Steens-Pueblo mining district, Erikson and Curry (1977) examined uranium prospects and observed that concentrations of oxidized uranium occur in narrow zones in and adjacent to rhyolite breccias and rhyolite dikes in the Pike Creek Formation (Walker and Repenning, 1965). These occurrences are possibly associated with high-angle fracture zones. Although Erikson and Curry (1977) noted that uranium surface shows are "**** weak, small, and sporadic," they also concluded that significant uranium mobilization had taken place. Uraniumbearing formations are not known to crop out, and no anomalous radioactive emissions were detected in the vicinity of high-angle faults in or near the Home Creek Wilderness Study Area.

Three low-temperature geothermal springs that lie along the flanks of the Blitzen Valley, about $12 \mathrm{mi}$ north of the study area, range in temperature from 78 to $89^{\circ} \mathrm{F}$ and produce from 100 to 1,800 gallons of water per minute that is used for livestock and irrigation (Waring, 1965). The Oregon Department of Geology and Mineral Industries (1982) classified the area around the springs as "**** known or inferred to be underlain at shallow depth (less than $350 \mathrm{ft}$ ) by thermal water of sufficient temperature for direct heat applications." No geothermal springs are known to emanate from structures in or near the study area.

Oil and gas leases issued in 1982-83 for most of the study area were terminated in 1984-85. Lands in wilderness study areas of the Steens Mountain region were assessed by Fouch (1983) as having low potential for petroleum resources; however, no geologic structures favorable for oil and gas are known to underlie this study area.

\section{Appraisal of Mineral Resources}

There are no identified mineral or energy resources or occurrences in the Home Creek Wilderness Study Area, and the host formations and depositional environment of the metallic and industrial minerals of the High Steens Wilderness Study Area (Minor and others, 1987) are not known to be present within or adjacent to this study area (Moyle, 1987).

\section{ASSESSMENT OF MINERAL RESOURCE POTENTIAL}

By Dean B. Vander Meulen, Andrew Griscom, Harley D. King, and Thomas L. Vercoutere U.S. Geological Survey

\section{Geology}

The Home Creek Wilderness Study Area is located along the west slope of Steens Mountain. Most of the slope, including the study area, is underlain by middle Miocene Steens Basalt (Piper and others, 1939; Baksi and others, 1967). Strata within the study area consistently dip $2^{\circ}$ to $6^{\circ}$ to the west, although direction and angle of dip vary greatly near the larger fault zones. In the study area, the Steens Basalt is made up of a thick, chemically homogeneous sequence of basalt flows that are typically 20 to 30 $\mathrm{ft}$ thick. Near the southern part of the study area along the Catlow Rim escarpment (fig. 2), the Steens Basalt has a minimum thickness of $1,900 \mathrm{ft}$; the base of the basalt unit is not exposed in the study area.

Along the north boundary of the study area in the canyon of Roaring Springs Creek (fig. 2), exposures of the Steens Basalt are unconformably overlain by an ash-flow tuff. Whole-rock and trace-element data (Hildreth, 1981) indicate that the tuff is probably correlative with part of the Devine Canyon Ash-flow Tuff, dated at 9.2 Ma (Walker, 1979). In this study area the tuff has a maximum thickness of about $50 \mathrm{ft}$. Isolated exposures of the Devine Canyon Ash-flow Tuff are also present in the southeast and central parts of the study area. Near the southeast boundary, exposures of the welded tuff typically form a pattern of low flat-topped ridges that probably reflect an inversion of paleotopography; that is, the welded tuff filled paleo-stream channels or depressions and was later exposed by preferential erosion of the surrounding rock. Exposures of the tuff in the study area represent distal facies of a caldera-forming ash-flow tuff eruption. Walker (1970) and Greene (1973) indicate that the Devine Canyon Ash-flow Tuff erupted from a caldera located within the Harney Basin, $50 \mathrm{mi}$ north of the study area.

West of the Catlow Rim is the Catlow Valley, a large irregular-shaped graben formed by basin and range 
extensional tectonism. During the Pleistocene, the valley was filled by Catlow Lake. Along the west boundary of the study area, wave-cut benches and shoreline deposits formed on Catlow Rim at various lake levels. The highest shoreline deposit is $4,795 \mathrm{ft}$ above sea level, about $250 \mathrm{ft}$ above the present valley floor. At least five major shorelines are exposed along the western part of the rim. The shorelines consist of beach and bar deposits and wavecut benches. Delta deposits form part of the shoreline where larger streams entered Catlow Lake. Shoreline deposits consist of partly sorted to sorted sand and gravel.

Patterned ground features, common in colluvium east of Catlow Rim, are probably the result of a combination of joint cracking, frost heave, mass wasting, and wind erosion (Ritter, 1978, p. 447). In the western part of the study area Holocene talus deposits locally cover large parts of the lower Catlow Rim escarpment. Along the base of the escarpment, lake shorelines are partly concealed by these deposits. Streams draining the western part of the study area have breached and eroded some of the shoreline bars, and in other locations alluvial stream deposits have buried the shorelines. South of the study area, dunes are common along the valley floor. Dunes $8 \mathrm{mi}$ south of the study area show several episodes of migration during the Holocene. Ancient artifacts are preserved in these dunes along with at least two major air-fall tuffs from Mount Mazama, dated at $0.007 \mathrm{Ma}$ (Mehringer and Wigand, 1984).

Three separate fault-set directions are recognized in the Home Creek Wilderness Study Area. The oldest and most conspicuous set is the northwest-trending range-front fault zone and parallel faults located along the base of the Catlow Rim escarpment (fig. 2). A second set of normal faults bounds a small north-trending graben in the northern part of the study area. The third and youngest set of normal faults strikes $\mathrm{N}$. $60^{\circ}-70^{\circ} \mathrm{W}$. and parallels fault-controlled drainage canyons in the west-central part of the study area.

The youngest faults truncate the north-trending graben (fig. 2) located in the northern part of the study area and are subparallel to a large fault-disrupted monocline that forms the western escarpment of the High Steens fault block $9 \mathrm{mi}$ northeast of the study area. The monocline and associated normal faults are considered to be part of the southern section of the Brothers fault zone, a deep-seated regional shear zone (Walker, 1969; Minor and others, 1987).

\section{Geochemical Studies}

In 1986-87, the U.S. Geological Survey conducted a reconnaissance geochemical study of the Home Creek Wilderness Study Area. The study included the collection and analysis of 15 rock samples, 27 stream-sediment samples, and 27 nonmagnetic heavy-mineral-concentrate samples from stream sediment. Stream-sediment samples and stream sediments from which the concentrates are derived were collected from active alluvium in stream channels.

Stream sediments represent a composite of rock and soil eroded upstream from the sample-collection sites. Nonmagnetic heavy-mineral concentrate samples provide information about the chemistry of rock material eroded from the drainage basin upstream from the sample-collection sites. The nonmagnetic fraction of heavy-mineral concentrates may contain many ore-forming or ore-related minerals. Selective concentration of minerals permits determination of some elements that are not easily detected in bulk stream-sediment samples. Most rock samples appeared fresh and unaltered and were collected to provide information on geochemical background concentrations. A few of the rock samples appeared altered and possibly mineralized; these were collected to determine the suite of elements associated with the observed alteration or mineralization.

All of the stream-sediment samples and heavy-mineral concentrates and four of the rock samples were analyzed semiquantitatively for 31 elements by using the directcurrent arc emission spectrographic method (Grimes and Marranzino, 1968). Eight of the rock samples were analyzed for 43 elements by using a similar method. Streamsediment samples and four of the rock samples were also analyzed by inductively coupled argon plasma atomicemission spectroscopy (ICAP-AES) for antimony, arsenic, bismuth, cadmium, and zinc and by atomic absorption for gold and mercury (Crock and others, 1987). Analytical data are by M.S. Erickson (written commun., 1987).

An anomalous concentration of silver (20 parts per million, or ppm) was detected in a nonmagnetic heavymineral-concentrate sample collected down slope from the Devine Canyon Ash-flow Tuff in the east-central part of the study area. The anomalous concentration may indicate silver mineralization associated with the ash-flow tuff or with faults and fractures within the tuff. An association between silver anomalies in stream-sediment samples and the ash-flow tuff is recorded in the Rincon Wilderness Study Area, $14 \mathrm{mi}$ south of the study area (Vander Meulen and others, 1988). No additional silver anomalies were detected in the study area.

Silver and silver-bearing minerals were not observed in the concentrate during microscopic examination. The sample contained iron oxide, a possible source of the silver. Iron oxides may become enriched in various metals, including silver, by adsorption or coprecipitation. Faults or fracture zones are possible avenues along which fluids may have migrated upward and precipitated mineral grains containing silver. Locations and trends of faults mapped in the region (fig. 2) suggest that a buried fault may be present.

On the basis of the size of the silver anomaly (20 $\mathrm{ppm}$ ), the absence of detected silver in other samples in the 
area, and the absence of detected anomalous concentrations of elements commonly associated with silver, we believe that the anomaly does not reflect a deposit of silver occurring at the surface in the Home Creek Wilderness Study Area. The silver anomaly could, however, reflect more mineralized rock at depth.

An anomalous concentration of lead in a nonmagnetic heavy-mineral-concentrate sample is probably due to a lead artifact, such as a bullet fragment. No other elements were detected in anomalous concentrations in these or other concentrate samples. No notably anomalous concentrations of ore-related elements were detected in stream-sediment samples collected in the Home Creek Wilderness Study Area.

\section{Geophysical Studies}

Geophysical investigation of the Home Creek Wilderness Study Area consisted of three kinds of geophysical surveys: aeromagnetic, gravity, and aerial gamma-ray spectrometer.

A regional aeromagnetic survey was flown over the study area (U.S. Geological Survey, 1972). Data were collected along parallel east-west flightlines spaced at 2-mi intervals and flown at a constant barometric elevation of $9,000 \mathrm{ft}$ above sea level. Additional aeromagnetic data are available in the atlas on the Adel $1^{\circ}$ by $2^{\circ}$ quadrangle published for the Department of Energy (Geodata International, Inc., 1980). These data consist of east-west profiles spaced at 3-mi intervals and flown at an average height of $400 \mathrm{ft}$ above the ground surface. Five of these profiles cross the wilderness study area.

Magnetic minerals, where locally concentrated or absent, may cause a high or low magnetic anomaly that can be a guide to mineral occurrences or deposits. Boundaries between magnetic and less magnetic rock units are located approximately at the steepest gradient on the flanks of the magnetic anomaly. The majority of the anomalies in the study area are probably caused by the preponderance of lava flows and other volcanic rocks because these rocks characteristically have high magnetic susceptibility. The major magnetic feature in the study area is a linear low extending over, and parallel to, the Catlow Rim. This magnetic anomaly is likely caused by the topographic effect of the $1,900-\mathrm{ft}$ scarp at the valley rim. The low may also reflect a reversely magnetized section of Steens Basalt (Mankinen and others, 1985).

A gravity survey of the general area was conducted by the U.S. Geological Survey in 1986 to supplement available data from the National Geophysical Data Center, Boulder, Colo., 80303. Station spacing ranged from about 3 to $5 \mathrm{mi}$, and nine stations are situated within or on the border of the study area. The data display a poorly defined gravity gradient that slopes down into a gravity low associated with Catlow Valley, probably caused by low-density sedimen- tary deposits filling the valley. The steepest part of the gradient is located over the range-front fault zone at the base of the Catlow Rim escarpment.

Radiometric data were collected and compiled by Geodata International, Inc. (1980) for the National Uranium Resource Evaluation (NURE) program of the Department of Energy. Aerial gamma-ray spectrometer measurements were made along east-west flight lines spaced at 3mi intervals. The recorded flight altitudes generally range from 200 to $400 \mathrm{ft}$ above the ground. Recordings were made of gamma-ray flux from radioactive isotopes of uranium, thorium, and potassium or their decay products. Abrupt shifts of recorded flux level occur over geologic contacts. Results indicate that statistically significant anomalies of uranium, potassium, and thorium are not present within the study area.

\section{Mineral Resource Assessment}

Part of a stream drainage and adjacent outcrops of ashflow tuff in the east-central part of the study area have low potential for silver resources, certainty level B (fig. 2). A heavy-mineral-concentrate sample collected from the drainage contains anomalous concentrations of silver. The Devine Canyon Ash-flow Tuff is exposed on a ridge $400 \mathrm{ft}$ west of, and up-slope from, the sample site. An association between silver anomalies in stream-sediment samples and anomalous concentrations of silver in the same ash-flow tuff is observed in the Rincon Wilderness Study Area, 10 mi south of this study area.

Pleistocene lake shoreline deposits located within and adjacent to the western part of the study area have moderate potential for sand and gravel resources, certainty level C (fig. 2). Similar deposits along the same shoreline $12 \mathrm{mi}$ south of the study area constitute gravel resources.

Geothermal hot springs issue from north- and northwest-trending fault zones $12 \mathrm{mi}$ north of the study area. Similar faults zones are located in the western and central parts of the study area and east of the study area. The fault zones and areas surrounding them include most of the study area; therefore, the entire study area has low potential, certainty level B, for geothermal energy.

Tertiary volcanic rocks underlying the Home Creek Wilderness Study Area are not sources of hydrocarbons. Furthermore, geologic structures favorable for the production of oil and gas are not known to underlie the study area. Pre-Tertiary basement rocks exposed about $25 \mathrm{mi}$ south of the study area are Mesozoic metamorphic and intrusive rocks (Walker and Repenning, 1965; Roback and others, 1987) and are unlikely sources for hydrocarbons. The absence of rocks capable of producing hydrocarbons and the minimal probability that such rocks exist at depth indicate that the study area has no potential for oil and gas, certainty level D. 


\section{REFERENCES CITED}

Baksi, A.K., York, D., and Watkins, N.D., 1967, Age of Steens Mountain geomagnetic polarity transition: Journal of Geophysical Research, v. 72, p. 6,299-6,308.

Beikman, H.M., Hinkle, M.E., Frieders, Twila, Marcus, S.M., and Edward, J.R., 1983, Mineral surveys by the Geological Survey and the Bureau of Mines of Bureau of Land Management Wilderness Study Areas: U.S. Geological Survey Circular 901, p.

Bradley, Robin, 1982, Mining districts and mineral deposits of the Basin and Range province of Oregon: U.S. Geological Survey Open-File Report 82-58, 14 p.

Crock, J.G., Briggs, P.H., Jackson, L.L., and Lichte, F.E., 1987, Analytical methods for the analysis of stream sediments and rocks from wildemess study areas: U.S. Geological Survey Open-File Report 87-84, 35 p.

Erikson, E.H., and Curry, W.E., 1977, Preliminary study of the uranium favorability of Tertiary rocks, southeastern Oregon; eastern Klamath, southern Lake, Harney, and western Malheur Counties: Grand Junction, Colo., Bendix Field Engineering Corp. report for U.S. Energy Research and Development Administration under contract No. EY-76-C13-1664, issued as U.S. Department of Energy Open-File Report GJBX-92(77), 18 p.

Fouch, T.D., 1983, Petroleum potential of wilderness lands, Oregon: U.S. Geological Survey Miscellaneous Investigations Series Map I-1544, scale 1:1,000,000.

Geodata International, Inc., 1980, Aerial radiometric and magnetic survey, National Topographic Map, Adel, Oregon [ $1^{\circ}$ by $2^{\circ}$ sheet; National Uranium Resource Evaluation Program]: U.S. Department of Energy Open-File Report GJBX-104 (80), v. 2, 145 p.

Goudarzi, G.H., 1984, Guide to preparation of mineral survey reports on public lands: U.S. Geological Survey Open-File Report 84-787, $51 \mathrm{p}$.

Greene, R.C., 1973, Petrology of the welded tuff of Devine Canyon, southeastern Oregon: U.S. Geological Survey Professional Paper 797, $26 \mathrm{p}$.

Grimes, D.J., and Marranzino, A.P., 1968, Direct-current arc and alternating-current spark emission spectrographic field methods for the semiquantitive analysis of geologic materials: U.S. Geological Survey Circular 591, 6 p.

Hildreth, Wes, 1981, Gradients in silicic chambers; implications for lithospheric magmatism: Journal of Geophysical Research, v. 86 , no. B11, p. 10,153-10,192.

Mankinen, E.A., Prevot, Michel, and Gromme, C.S., 1985, The Steens Mountain (Oregon) geomagnetic polarity transition1. Directional history, duration of episodes, and rock magnetism: Journal of Geophysical Research, v. 90, no. B12, p. $10,393-10,416$.

McKelvey, V.E., 1972, Mineral resource estimates and public policy: American Scientist, v. 60, p. 32-40.

Mehringer, P.J., Jr., and Wigand, P.E., 1984, Holocene history of Skull Creek dunes, Catlow Valley, southeastern Oregon, U.S.A.: Journal of Arid Environments, 11, 117-138.

Minor, S.A., Plouff, Donald, Esparza, L.E., and Peters, T.J., 1987.
Mineral resources of the High Steens and Little Blitzen Gorge Wilderness Study Areas, Harney County, Oregon: U.S. Geological Survey Bulletin 1740-A, 21 p.

Moyle, P.R., 1987, Mineral resources of the Home Creek Wilderness Study Area, Harney County, Oregon: U.S. Bureau of Mines Open-File Report MLA 58-87, 13 p..

Myers, A.T., Haven, R.G., and Dunton, P.J., 1961, A spectrochemical method for the semiquantitative analysis of rocks, minerals, and ores: U.S. Geological Survey Bulletin 1084-I, p. 207-229.

Oregon Department of Geology and Mineral Industries, 1982, Geothermal resources of Oregon: National Oceanic and Atmospheric Administration, National Geophysical Data Center map, produced for U.S. Department of Energy, scale 1:500,000.

Piper, A.M., Robinson, T.W., Jr., and Parks, C.F., Jr., 1939, Geology and ground-water resources of the Harney Basin, Oregon: U.S. Geological Survey Water-Supply Paper 841, $189 \mathrm{p}$.

Ritter, D.F., 1978, Process geomorphology: Dubuque, Iowa, Wm. C. Brown Co., 603 p.

Ross, C.P., 1942, Quicksilver deposits in the Steens and Pueblo Mountains, southem Oregon: U.S. Geological Survey Bulletin 931-J, p. 227-258.

Roback, R.C., Vander Meulen, D.B., King, H.D., Plouff, Donald, Munts, S.R., and Willett, S.L., 1987, Mineral resources of the Pueblo Mountains Wilderness Study Area, Hamey County, Oregon and Humboldt County, Nevada: U.S. Geological Survey Bulletin 1740-B, 30 p., scale 1:48,000.

U.S. Bureau of Mines and U.S. Geological Survey, 1980, Principles of a resource/reserve classification for minerals: U.S. Geological Survey Circular 831, 5 p.

U.S. Geological Survey, 1972, Aeromagnetic map of the Adel and parts of the Burns, Boise, and Jordan Valley $1^{\circ}$ by $2^{\circ}$ quadrangles, Oregon: U.S. Geological Survey open-file report, scale $1: 250,000$.

Vander Meulen, D.B., Plouff, Donald, King, H.D., and Mayerle, R.T., 1988, Mineral Resources of the Rincon Wilderness Study Area, Harney County, Oregon: U.S. Geological Survey Bulletin 1740-E, 26 p.

Walker, G.W., 1969, Geology of the High Lava Plains province, in Mineral and water resources of Oregon: Oregon Department of Geology and Mineral Industries Bulletin 64, p. 77-79. 1970 , Cenozoic ash-flow tuffs of Oregon: The Ore Bin, v. 32 , no. 6 , p. $97-115$.

1979, Revisions to the Cenozoic stratigraphy of Harney Basin, southeastern Oregon: U.S. Geological Survey Bulletin $1475,35 \mathrm{p}$.

Walker, G.W., and Repenning, C.A., 1965, Reconnaissance geologic map of the Adel quadrangle, Lake, Harney, and Malheur Counties, Oregon: U.S. Geological Survey Miscellaneous Geological Investigations Map I-446, scale 1:250,000.

Waring, G.A., 1965, Thermal springs of the United States and other countries of the world, a summary: U.S. Geological Survey Professional Paper 492, 383 p.

Williams, Howel, and Compton, R.R., 1953, Quicksilver deposits of Steens Mountain and Pueblo Mountains, southeast Oregon: U.S. Geological Survey Bulletin 995-B, p. 19-77. 
APPENDIXES 


\section{DEFINITION OF LEVELS OF MINERAL RESOURCE POTENTIAL AND CERTAINTY OF ASSESSMENT}

\section{LEVELS OF RESOURCE POTENTIAL}

H HIGH mineral resource potential is assigned to areas where geologic, geochemical, and geophysical characteristics indicate a geologic environment favorable for resource occurrence, where interpretations of data indicate a high degree of likelihood for resource accumulation, where data support mineral-deposit models indicating presence of resources, and where evidence indicates that mineral concentration has taken place. Assignment of high resource potential to an area requires some positive knowledge that mineral-forming processes have been active in at least part of the area.

$M$ MODERATE mineral resource potential is assigned to areas where geologic, geochemical, and geophysical characteristics indicate a geologic environment favorable for resource occurrence, where interpretations of data indicate reasonable likelihood for resource accumulation, and (or) where an application of mineral-deposit models indicates favorable ground for the specified type(s) of deposits.

L LOW mineral resource potential is assigned to areas where geologic, geochemical, and geophysical characteristics define a geologic environment in which the existence of resources is permissive. This broad category embraces areas with dispersed but insignificantly mineralized rock, as well as areas with little or no indication of having been mineralized.

$\mathrm{N} \quad$ NO mineral resource potential is a category reserved for a specific type of resource in a well-defined area.

$U$ UNKNOWN mineral resource potential is assigned to areas where information is inadequate to assign a low, moderate, or high level of resource potential.

\section{LEVELS OF CERTAINTY}

A Available information is not adequate for determination of the level of mineral resource potential.

B Available information only suggests the level of mineral resource potential.

C Available information gives a good indication of the level of mineral resource potential.

D Available information clearly defines the level of mineral resource potential.

\begin{tabular}{|c|c|c|c|}
\hline A & $\mathrm{B}$ & C & $\mathrm{D}$ \\
\hline \multirow{5}{*}{ UNKNOWN POTENTIAL } & $H / B$ & $H / C$ & H/D \\
\hline & HIGH POTENTIAL & HIGH POTENTIAL & HIGH POTENTIAL \\
\hline & $\begin{array}{c}\text { M/B } \\
\text { MODERATE POTENTIAL }\end{array}$ & $\begin{array}{c}\mathrm{M} / \mathrm{C} \\
\text { MODERATE POTENTIAL }\end{array}$ & $\begin{array}{c}\text { M/D } \\
\text { MODERATE POTENTIAL. }\end{array}$ \\
\hline & \multirow[t]{2}{*}{$\begin{array}{c}\text { L/B } \\
\text { LOW POTENTIAL }\end{array}$} & \multirow[t]{2}{*}{$\begin{array}{c}\text { L/C } \\
\text { LOW POTENTIAL }\end{array}$} & $\begin{array}{c}\text { L/D } \\
\text { LOW POTENTIAL }\end{array}$ \\
\hline & & & $\begin{array}{c}\text { N/D } \\
\text { NO POTENTIAL. }\end{array}$ \\
\hline
\end{tabular}

LEVEL OF CERTAINTY

Abstracted with minor modifications from:

Taylor, R.B., and Steven, T.A., 1983, Definition of mineral resource potential: Economic Geology, v. 78, no. 6, p. 1268-1270.

Taylor, R.B., Stoneman, R.J., and Marsh, S.P., 1984, An assessment of the mineral resource potential of the San isabel National Forest, south-central Colorado: U.S. Geological Survey Bulletin 1638, p. 40-42.

Goudarzi, G.H., compiler, 1984, Guide to preparation of mineral survey reports on public lands: U.S. Geological Survey Open-File Report 84-0787, p. 7, 8. 
RESOURCE/RESERVE CLASSIFICATION

\begin{tabular}{|c|c|c|c|c|c|}
\hline & \multicolumn{3}{|c|}{ IDENTIFIED RESOURCES } & \multirow{2}{*}{\multicolumn{2}{|c|}{$\frac{\text { UNDISCOVERED RESOURCES }}{\text { Probability Range }}$}} \\
\hline & \multicolumn{2}{|c|}{ Demonstrated } & \multirow{2}{*}{ Inferred } & & \\
\hline & Measured & Indicated & & Hypothetical & Speculative \\
\hline ECONOMIC & \multicolumn{2}{|c|}{$\begin{array}{c}1 \\
\text { Reserves }\end{array}$} & $\begin{array}{l}\text { Inferred } \\
\text { Reserves }\end{array}$ & \multicolumn{2}{|c|}{1} \\
\hline $\begin{array}{l}\text { MARGINALLY } \\
\text { ECONOMIC }\end{array}$ & \multicolumn{2}{|c|}{$\begin{array}{l}\text { Marginal } \\
\text { Reserves }\end{array}$} & $\begin{array}{l}\text { Inferred } \\
\text { Marginal } \\
\text { Reserves }\end{array}$ & \multicolumn{2}{|c|}{$-1-$} \\
\hline $\begin{array}{c}\text { SUB- } \\
\text { ECONOMIC }\end{array}$ & \multicolumn{2}{|c|}{$\begin{array}{l}\text { Demonstrated } \\
\text { Subeconomic } \\
\text { Resources }\end{array}$} & $\begin{array}{l}\text { Inferred } \\
\text { Subeconomic } \\
\text { Resources }\end{array}$ & \multicolumn{2}{|c|}{ I } \\
\hline
\end{tabular}

Major elements of mineral resource classification, excluding reserve base and inferred reserve base. Modified from McKelvey, V.E., 1972, Mineral resource estimates and public policy: American Scientist, v. 60, p. 32-40; and U.S. Bureau of Mines and U.S. Geological Survey, 1980, Principles of a resource/reserve classification for minerals: U.S. Geological Survey Circular 831, p. 5. 
Terms and boundary ages used by the U.S. Geological Survey in this report

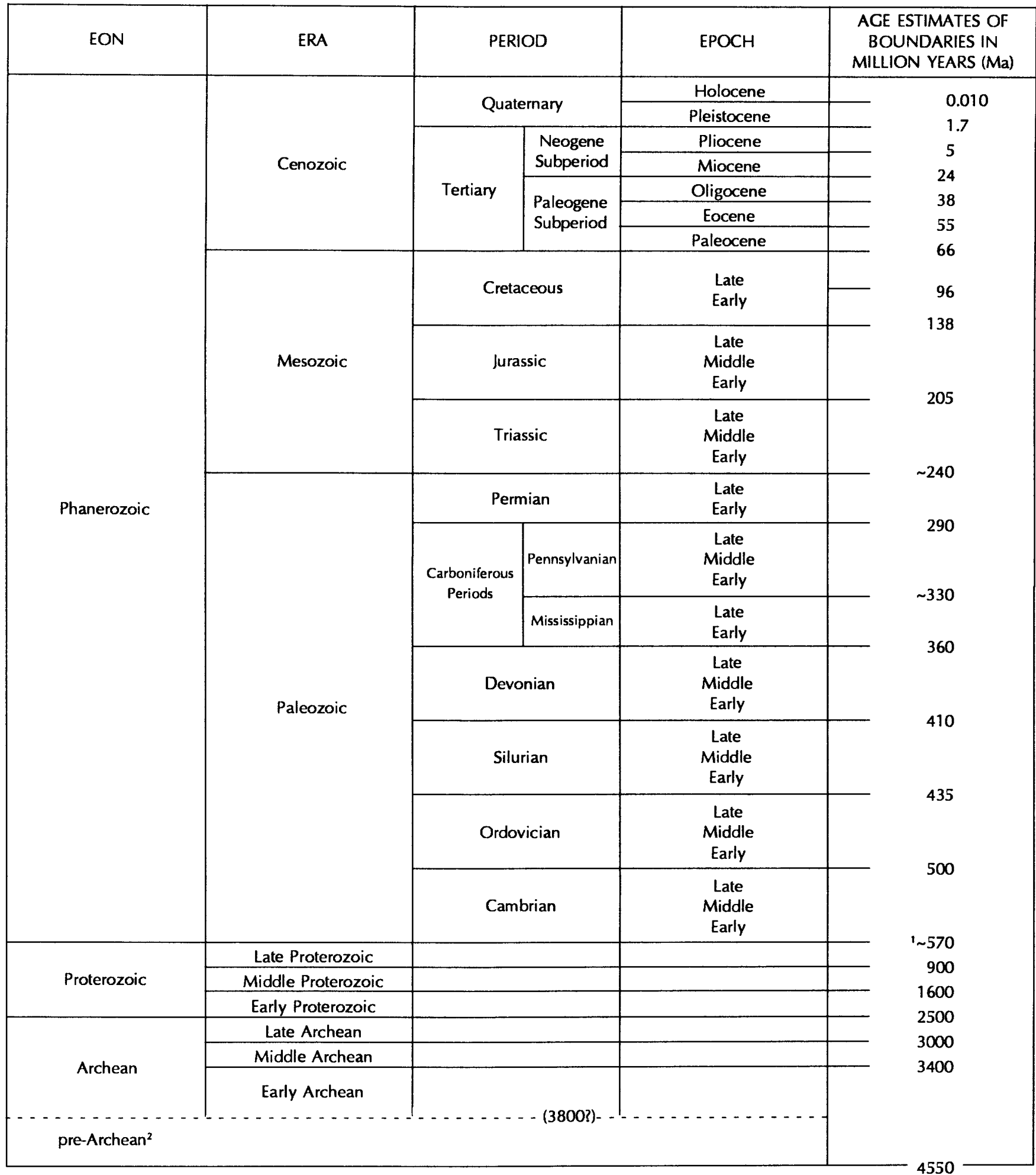

'Rocks older than $570 \mathrm{Ma}$ also called Precambrian, a time term without specific rank.

${ }^{2}$ Informal time term without specific rank. 



\section{SELECTED SERIES OF U.S. GEOLOGICAL SURVEY PUBLICATIONS}

\section{Perlodicals}

Earthquakes \& Volcanoes (issued bimonthly).

Preliminary Determination of Epicenters (issued monthly).

\section{Technical Books and Reports}

Professional Papers are mainly comprehensive scientific reports of wide and lasting interest and importance to professional scientists and engineers. Included are reports on the results of resource studies and of topographic, hydrologic, and geologic investigations. They also include collections of related papers addressing different aspects of a single scientific topic.

Bulletins contain significant data and interpretations that are of lasting scientific interest but are generally more limited in scope or geographic coverage than Professional Papers. They include the results of resource studies and of geologic and topographic investigations; as well as collections of short papers related to a specific topic.

Water-Supply Papers are comprehensive reports that present significant interpretive results of hydrologic investigations of wide interest to professional geologists, hydrologists, and engineers. The series covers investigations in all phases of hydrology, including hydrogeology, availability of water, quality of water, and use of water.

Circulars present administrative information or important scientific information of wide popular interest in a format designed for distribution at no cost to the public. Information is usually of short-term interest.

Water-Resources Investigations Reports are papers of an interpretive nature made available to the public outside the formal USGS publications series. Copies are reproduced on request unlike formal USGS publications, and they are also available for public inspection at depositories indicated in USGS catalogs.

Open-File Reports include unpublished manuscript reports, maps, and other material that are made available for public consultation at depositories. They are a nonpermanent form of publication that may be cited in other publications as sources of information.

\section{Maps}

Geologic Quadrangle Maps are multicolor geologic maps on topographic bases in $71 / 2$ - or 15 -minute quadrangle formats (scales mainly $1: 24,000$ or $1: 62,500$ ) showing bedrock, surficial, or engineering geology. Maps generally include brief texts; some maps include structure and columnar sections only.

Geophysical Investigations Maps are on topographic or planimetric bases at various scales; they show results of surveys using geophysical techniques, such as gravity, magnetic, seismic, or radioactivity, which reflect subsurface structures that are of economic or geologic significance. Many maps include correlations with the geology.

Miscellaneous Investigations Series Maps are on planimetric or topographic bases of regular and irregular areas at various scales; they present a wide variety of format and subject matter. The series also includes 7 1/2-minute quadrangle photogeologic maps on planimetric bases which show geology as interpreted from aerial photographs. Series also includes maps of Mars and the Moon.
Coal Investigations Maps are geologic maps on topographic or planimetric bases at various scales showing bedrock or surficial geology, stratigraphy, and structural relations in certain coal-resource areas.

Oil and Gas Investigations Charts show stratigraphic information for certain oil and gas fields and other areas having petroleum potential.

Miscellaneous Field Studies Maps are multicolor or black-andwhite maps on topographic or planimetric bases on quadrangle or irregular areas at various scales. Pre-1971 maps show bedrock geology in relation to specific mining or mineral-deposit problems; post-1971 maps are primarily black-and-white maps on various subjects such as environmental studies or wildemess mineral investigations.

Hydrologic Investigations Atiases are multicolored or black-andwhite maps on topographic or planimetric bases presenting a wide range of geohydrologic data of both regular and irregular areas; principal scale is $1: 24,000$ and regional studies are at $1: 250,000$ scale or smaller.

\section{Catalogs}

Permanent catalogs, as well as some others, giving comprehensive listings of U.S. Geological Survey publications are available under the conditions indicated below from the U.S. Geological Survey, Books and Open-File Reports Section, Federal Center, Box 25425, Denver, CO 80225. (See latest Price and Availability List.)

"Publications of the Geological Survey, 1879- 1961" may be purchased by mail and over the counter in paperback book form and as a set of microfiche.

"Publications of the Geological Survey, 1962- 1970" may be purchased by mail and over the counter in paperback book form and as a set of microfiche.

"Publications of the U.S. Geological Survey, 1971-1981" may be purchased by mail and over the counter in paperback book form (two volumes, publications listing and index) and as a set of microfiche.

Supplements for 1982,1983,1984, 1985, 1986, and for subsequent years since the last permanent catalog may be purchased by mail and over the counter in paperback book form.

State catalogs, "List of U.S. Geological Survey Geologic and Water-Supply Reports and Maps For (State)," may be purchased by mail and over the counter in paperback booklet form only.

"Price and Avallability List of U.S. Geological Survey Publications," issued annually, is available free of charge in paperback booklet form only.

Selected copies of a monthly catalog "New Publications of the U.S. Geological Survey" av ailable free of charge by mail or may be obtained over the counter in paperback booklet form only. Those wishing a free subscription to the monthly catalog "New Publications of the U.S. Geological Survey" should write to the U.S. Geological Survey, 582 National Center, Reston, VA 22092.

Note.--Prices of Government publications listed in older catalogs, announcements, and publications may be incorrect. Therefore, the prices charged may differ from the prices in catalogs, announcements, and publications. 


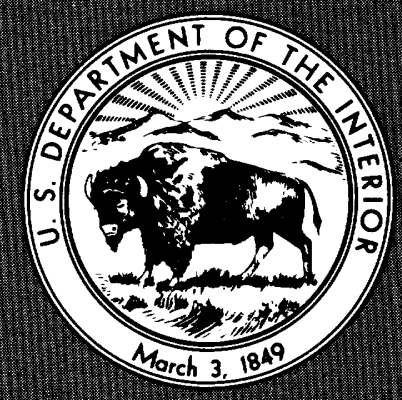

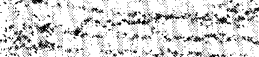

(

2

-

(1)

A

,

Hets

$$
\frac{1}{3}
$$

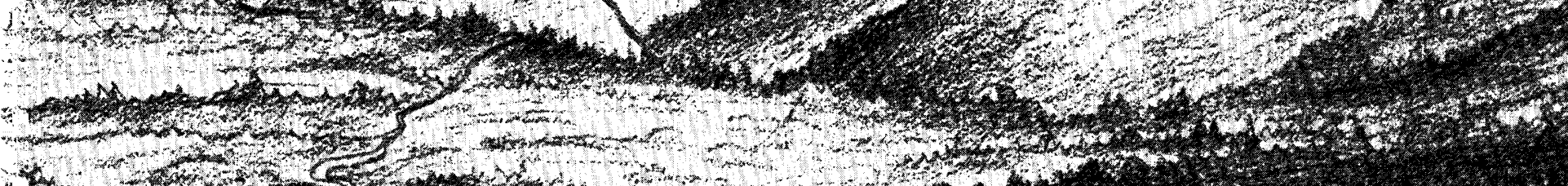

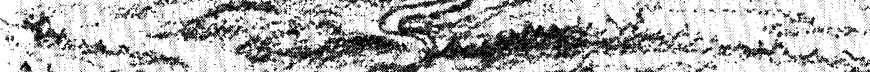

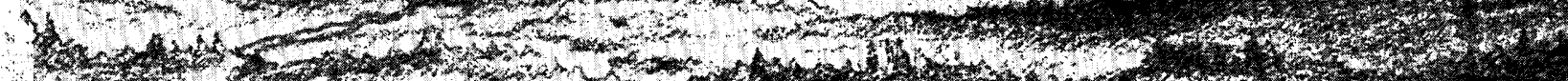

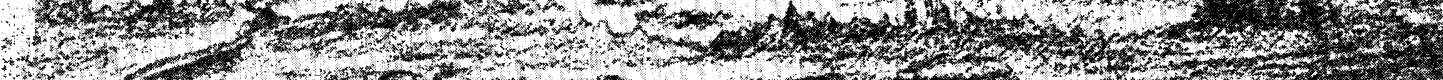

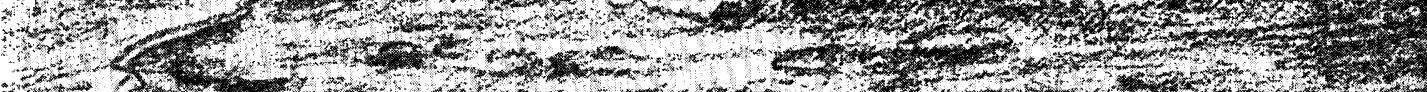

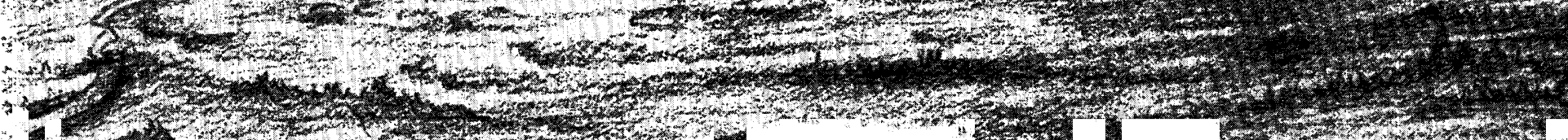

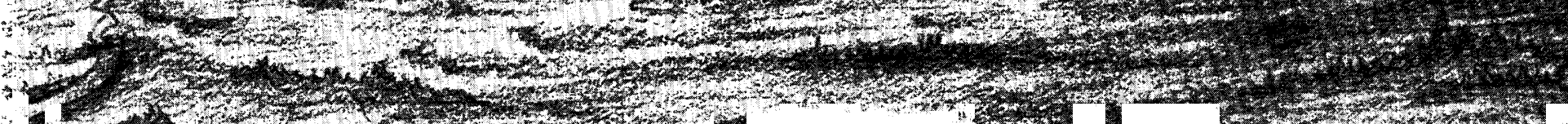

(1) 